\title{
PREVALENCE AND CLINICAL IMPORTANCE OF CRYPTOSPORIDIUM AND GIARDIA IN HUMAN AND ANIMALS
}

\author{
M. A. Ehsan ${ }^{1 *}$, M. Akter ${ }^{1}$, M. Ahammed ${ }^{2}$, M. A. Ali ${ }^{3}$ and M. U. Ahmed ${ }^{1}$ \\ ${ }^{1}$ Department of Medicine, ${ }^{2}$ Department of Pharmacology, Faculty of Veterinary Science, Bangladesh \\ Agricultural University, Mymensingh-2202, Bangladesh; ${ }^{3}$ Department of Pathology and Parasitology, Jhenaidah \\ Govt. Veterinary College, Jhenaidah
}

\begin{abstract}
The protozoan parasites Cryptosporidium and Giardia duodenalis are worldwide considered as an important cause of gastrointestinal disease in human patients and in animals. The high number of (oo) cysts excreted shortly after infection, together with the low infectious dose, results in an easy spread of infection. The aim of this literature review is to introduce Cryptosporidium and Giardia by addressing their taxonomy, life cycle, prevalence and clinical importance for both human and animals.
\end{abstract}

Key words: Prevalence, Cryptosporidium, Giardia, Clinical importance

\section{INTRODUCTION}

Access to safe drinking water and basic sanitation is a fundamental human right, but currently more than one billion people worldwide do not have access to either safe drinking water or adequate sanitation. It is estimated that almost $60 \%$ of deaths following diarrhoeal diseases in developing countries are attributable to lack of access to safe drinking water and basic sanitation, children under 5 being at the highest risk. Important water-borne diarrhoeal diseases are cryptosporidiosis and giardiosis (Xiao and Fayer, 2008; Geurden et al., 2009). These diseases are caused by the protozoan parasites Cryptosporidium and Giardia, respectively, which are able to cause disease in humans and animals. Because of their impact on socio-economic development, especially in developing countries, both Cryptosporidium and Giardia are since 2004 included in the 'Neglected Disease Initiative' of the World Health Organization (WHO) (Savioli et al., 2006).

However, Cryptosporidium and Giardia also pose an important risk on the safety of drinking water in developed countries. For example, in 1993 more than 400,000 people were affected by cryptosporidiosis in Milwaukee (Wisconsin, USA) due to an ineffective filtration process in the production of drinking water. Since this outbreak screening of tap water for the presence of Cryptosporidium has become compulsory in the UK, The Netherlands and the USA, but water-borne outbreaks are still reported on a regular basis.

The aim of this literature review is to introduce Cryptosporidium and Giardia by addressing their taxonomy, life cycle, prevalence and clinical importance for both human and animals.

\section{Prevalence of Cryptosporidium in humans}

In developed countries, the prevalence of Cryptosporidium generally is low in asymptomatic people $(<1 \%)$ and in patients with diarrhoea (1-2\%) (Current and Garcia, 1991; Guerrant, 1997; Geurden et al., 2009). In developing countries, high rates of asymptomatic carriage (10-30\%) are common in comparison to patients with gastroenteritis (3-20\%) (Current and Garcia, 1991; Haque et al., 2003). Among the common Cryptosporidium species in humans, C. parvum and C. hominis are responsible for $>90 \%$ of human cases of cryptosporidiosis in developed nations (Xiao and Feng, 2008). The distribution of C. parvum and C. hominis in humans differs between geographic regions. In Europe, both $C$. parvum and C. hominis are common in humans (Leoni et al., 2006; Chalmers et al., 2009; Zintl et al., 2009). In the Middle East, C. parvum is the dominant species in humans

*Corresponding e-mail address: amimul.med@bau.edu.bd

Copyright (C) 2016 Bangladesh Society for Veterinary Medicine

All rights reserved 0361/2016 


\section{A. Ehsan and Others}

(Sulaiman et al., 2005; Pirestani et al., 2008). Geographic variations in the distribution of $C$. parvum and $C$. hominis can also occur within a country. For example, $C$. parvum is more common than $C$. hominis in rural areas in the United States and Ireland (Feltus et al., 2006; Zintl et al., 2009). In the rest of the world, especially developing countries, $C$. hominis is usually the predominant species in humans, responsible for $70-90 \%$ of the infections (Xiao and Feng, 2008). This suggests that zoonotic infection is much less common in developing countries than in developed countries.

Temporal and age-associated differences in the distribution of $C$. parvum and $C$. hominis infections have been reported. Peaks in Cryptosporidium infections have been observed in spring and late summer (Casemore, 1990). C. parvum was more prevalent in spring (in Ireland, the United Kingdom and New Zealand) and C. hominis was more prevalent in autumn (in the Netherlands, the United Kingdom and New Zealand) (McLauchlin et al., 2000; Learmonth et al., 2003, 2004; Hunter et al., 2004; Wielinga et al., 2008; Chalmers et al., 2009; Zintl et al., 2009). In The Netherlands, $C$. hominis was more commonly found in children and $C$. parvum more in adults (Wielinga et al., 2008). In the UK, C. hominis was more prevalent in infants less than one year, females aged 15 44 years and international travelers (Chalmers et al., 2008, 2009). C. viatorum was identified among travellers with gastro-intestinal symptoms returning to Great Britain from the Indian subcontinent (Elwin et al., 2012). In South American countries, a relatively high proportion of $C$. meleagridis infections has been identified in children and in immunocompromised patients (Cama et al., 2007, 2008; Meireles, 2010).

\section{Clinical importance}

Cryptosporidium is reported to infect people in at least 106 countries (Fayer, 2008). The most common clinical feature of cryptosporidiosis is diarrhoea. Characteristically, the diarrhoea is profuse and watery; it may contain mucus but rarely blood and leucocytes and it is often associated with weight loss. Other less common clinical features include abdominal pain, nausea, vomiting and low-grade fever. Occasionally, nonspecific symptoms such as myalgia, weakness, malaise, headache and anorexia occur (Current and Garcia, 1991).

The severity of a Cryptosporidium infection can vary from an asymptomatic shedding of oocysts to a severe and life-threatening disease. The duration and the severity of the symptoms and the outcome may vary with host factors such as the immune status of the person. Most immunocompetent persons experience a short-term illness with complete and spontaneous recovery (Current and Garcia, 1991). However, for immunocompromised patients, cryptosporidiosis can be a critical illness with persistent symptoms leading to dehydration and wasting (O’Donoghue, 1995; Chen et al., 2002; Blackburn et al., 2004), and eventually leading to death (Juranek, 1995; Manabe et al., 1998). In addition, Cryptosporidium infections can cause atypical manifestations in immunocompromised patients, such as biliary tract disease, respiratory tract disease and pancreatitis (Hunter and Nichols, 2002).

The severity of the infection is also related to the age of the patient. Diarrhoea is a leading cause of illness and death among children aged $<5$ years in developing countries and Cryptosporidium is one of the most important diarrhoeal pathogens (Shirley et al., 2012). Children are more likely to be infected with Cryptosporidium, which can be explained by a lack of an effective immunity at this age. In a study of 191 children with $C$. parvum in Uganda, $13 \%$ died, compared with $6 \%$ for children without $C$. parvum (Tumwine et al., 2003). Wielinga et al. (2008) found that the majority (80\%) of the human cases were children aged between 0 and 9 years and $>70 \%$ of these were caused by $C$. hominis. $C$. hominis is more common than $C$. parvum in children and is associated with heavier infections and greater growth shortfalls, even in the absence of symptoms (Bushen et al., 2007). Patients $>25$ years of age were infected mainly with $C$. parvum.

The clinical symptoms may also depend on the parasite species involved. Infections with $C$. hominis are associated with diarrhoea, nausea, vomiting, malaise and non-intestinal sequelae such as joint pain, eye pain, recurrent headache and fatigue, whereas infections with $C$. parvum, C. meleagridis, C. canis and $C$. felis cause only diarrhoea (Bouzid et al., 2013).

\section{Prevalence of Cryptosporidium in animals}

Cattle are commonly infected with $C$. parvum, C. andersoni, C. bovis and C. ryanae (Xiao, 2010). In dairy cattle, $C$. parvum is mostly found in pre-weaned calves, $C$. bovis and $C$. ryanae in weaned calves and $C$. andersoni in yearlings and adult cattle (Fayer et al., 2006b, 2007; Santín et al., 2008). Parasite prevalence varies from $1 \%$ (Kváč et al., 2006) to 59\% (Olson et al., 1997) in individual calves and up to $100 \%$ on farm level 
(Santín et al., 2004). The highest prevalence is observed in calves under the age of 5 weeks (Quílez et al., 1996). The prevalence of Cryptosporidium in flocks of small ruminants varies considerably, ranging from $5 \%$ to $70 \%$ for sheep and from 5\% to $35 \%$ for goats. This difference in prevalence results can be explained by differences in age of the animals, management, and diagnostic methods applied (Robertson, 2009). C. xiaoi,C. ubiquitum and C. parvumare the predominant species in small ruminants (Ryan et al., 2005; Goma et al., 2007; Santín et al., 2007; Geurden et al., 2008a; Mueller-Doblies et al., 2008; Pritchard et al., 2007, 2008; Quílez et al., 2008; Yang et al., 2009; Díaz et al., 2010; Wang et al., 2010; Tzanidakis et al., 2014).

In pigs, herd prevalences range from $8 \%$ to $100 \%$ with individual animal infection rates of between $1 \%$ and 34\%. C. suis (36-83\%) and C. scrofarum (formerly Cryptosporidium pig genotype II) (9-61\%) are the major Cryptosporidium spp. (Kváč et al., 2009; Chen et al., 2011; Budu-Amoako et al., 2012). C.suis preferentially infects suckling piglets, whereas C. scrofarum is more frequently found in weaners (Langkjaer et al., 2007; Johnson et al., 2008; Kváč et al., 2009; Yin et al., 2013; Zhang et al., 2013). Occasionally, C. muris (Kváč et al., 2009; Budu-Amoako et al., 2012; Němejc et al., 2013) or C. tyzzeri (Kváč et al., 2012) are found in pigs. With the exception of one study where $C$. parvum was the predominant species (Farzan et al., 2011), this speciesis less frequently found in pigs, suggesting that pigs are not an important source of zoonotic transmission (Chen and Huang, 2007; Zintl et al., 2009; Budu-Amoako et al., 2012; de la Fé Rodríguez et al., 2013; Němejc et al., 2013).

Low prevalences of Cryptosporidium have been reported in horses in the USA (7\%) and Italy (8\%) (Burton et al., 2010; Veronesi et al., 2010). Both C. parvum and Cryptosporidium horse genotype were found in horses (Ryan et al., 2003; Chalmers et al., 2005; Grinberg et al., 2008; Veronesi et al., 2010) and rarely the hedgehog genotype (Laatamna et al., 2013). These findings support a potential role of infected horses in zoonotic transmission.

A Cryptosporidium prevalence ranging from $0 \%$ to $13 \%$ has been reported in privately owned and stray dogs (Chermette and Blondel, 1989; Grimason et al., 1993; Diaz et al., 1996; Giangaspero et al., 2006; Claerebout et al., 2009; Yoshiuchi et al., 2010; Bajer et al., 2011). Most infections in dogs are caused by the host-specific $C$. canis. In addition to $C$. canis, other Cryptosporidium spp. were detected occasionally in dogs such as $C$. Muris (Lupo et al., 2008; Ellis et al., 2010), C. Parvum (Hajdušek et al., 2004; Giangaspero et al., 2006; Sotiriadou et al., 2013) and C. Meleagridis (Hajdušeket al., 2004). Thus the risk of zoonotic transmission from Cryptosporidium-infected dogs is low (Lucio-Foster et al., 2010; Uehlinger et al., 2013).

Cryptosporidium has been detected in cats with a range of $2 \%$ to $25 \%$ (Rambozzi, et al., 2007; Hoopes et al., 2013). In addition to the cat specific species, C. felis, C. parvum and C. muris were also identified (Palmer et al., 2008; Yoshiuchi et al., 2010; FitzGerald et al., 2011; Scorza et al., 2011; Sotiriadou et al., 2013).

\section{Veterinary importance}

C. parvum is a well-known cause of diarrhoea in neonatal ruminants. Clinical symptoms are most frequently observed in calves between the age of 5 days and 1 month and include profuse watery diarrhoea with acute onset, lethargy, anorexia and dehydration, which is usually self-limiting within 2 weeks (O'Handley et al., 1999, Schnyder et al., 2009). Mortality is variable and is most often observed in calves with multiple infections and in certain beef breeds, such as the Belgian Blue and White (de Graaf et al., 1999) and it can be as high as 30\% (Olson et al., 2004). However, morbidity in endemic herds can be as high as 100\% (Santín et al., 2008). Abomasal cryptosporidiosis, caused by $C$. andersoni, does not result in any visible clinical signs (Kváč et al., 2008). Infections with $C$. andersoni do not cause diarrhoea and follow a more chronic course than infections with C. parvum (Kváč and Vitovec, 2003). C. andersoni infections may result in a decrease in daily weight gain, decreased feed efficiency and less milk production (Anderson, 1987; Esteban and Anderson, 1995; Ralston et al., 2003).

Cryptosporidium is a major cause of neonatal diarrhoea in lambs, usually within the first 2 weeks of life and diarrhoea can be mild to severe. Cryptosporidiosis outbreaks in lambs are most common in crowded flocks and are associated with a decrease in liveweight, dressing percentage, growth rate and carcass productivity (Angus et al., 1982; Alonso-Fresán et al., 2005; Sweeny et al., 2011; de Graaf et al., 1999; Sari et al., 2009). Caprine cryptosporidiosis is characterised by diarrhoea and mortality in kids. Morbidity can reach 100\% and mortality 50\% in some herds (Vieira et al., 1997; Johnson et al., 1999; Sevinc, et al., 2005; Paraud et al., 2010; Santín, 2013). 


\section{A. Ehsan and Others}

Diarrhoea is the major clinical sign in foals affected by cryptosporidiosis. Foals are more susceptible to the infection than older animals (Grinberg et al., 2003; 2009; Veronesi et al., 2010) and most Cryptosporidium infections in adult horses are asymptomatic (Majewska et al., 2004; Sturdee et al., 2003).

Inappetance, depression, vomiting and/or diarrhoea developed in piglets experimentally infected with C. parvum, whereas mild or no clinical signs developed with $C$. suis (Enemark et al., 2003). However, an association between diarrhoea and infections with C. suisand C. scrofarum in nursing piglets has been described (Hamnes $e t$ al., 2007). In contrast, other studies did not find any significant association between diarrhoea and cryptosporidial infections (Quilez et al., 1996; Maddox-Hyttel et al., 2006, Vitovec et al., 2006).

Cryptosporidiosis in dogs has been reported in both asymptomatic and diarrhoeic dogs (Santín and Trout, 2008). Infections with $C$. canis are usually asymptomatic but severe diarrhoea, malabsorption, weakness and weight loss have been reported (Irwin, 2002; Miller et al., 2003). Dogs infected with C. muris showed chronic vomiting and profuse diarrhoea in one study (Ellis et al., 2010) but in another study no gastrointestinal signs were observed (Lupo et al., 2008).

Cryptosporidium oocysts were detected more frequently in cats without diarrhoea than in cats with diarrhoea (Sabshin et al., 2012) and shedding of Cryptosporidium oocysts without the presence of clinical signs was reported in experimentally and naturally infected cats (Mtambo et al., 1991; Nash et al., 1993; Fayer et al., 2006c). However, oocysts were also detected in the faeces of cats with persistent diarrhoea (Goodwin and Barsanti, 1990; Lent et al., 1993; Morgan et al., 1998).

\section{Prevalence of Giardia in humans}

In developed countries Giardia is detected in up to $14 \%$ of symptomatic patients and $2 \%$ in asymptomatic humans (Geurden et al., 2009; Homan and Mank, 2001). In developing countries, the prevalence of giardiosis in patients with diarrhoea is around 20\%, ranging from 5-43\% (Islam, 1990; Haque et al., 2005). Giardia infections are very common in children in developing countries (Farthing, 1994; Rabbani and Islam, 1994). Giardia assemblages $\mathrm{A}$ and $\mathrm{B}$ are considered more infectious for humans, with the latter being more prevalent. Subassemblage AII is more prevalent in humans than AI and is distributed globally, except in Asia and Australia. Assemblage AIII has not yet been detected in humans (Sprong et al., 2009). The geographic distribution of subassemblages BIII and BIV in human shows marked difference between continents. In Africa, infection with BIII is more prevalent $(81 \%)$ than with BIV, whereas the opposite is found in North America where $86 \%$ of infections are associated with BIV and $14 \%$ with BIII. A more balanced distribution was found in Australia and Europe (Sprong et al., 2009). To a much lesser extent, assemblage C, D, E and F were identified in human samples (Gelanew et al., 2007; Foronda et al., 2008). However, it remains unclear whether the presence of these assemblages in human stool is due to patent infections or merely represents passage through the intestinal tract.

\section{Clinical importance}

Approximately 200 million people in Asia, Africa and Latin America have symptomatic infections with about 50,000 cases reported each year (Xiao and Fayer, 2008). In symptomatic patients, mostly children, the severity of symptoms and the duration of Giardia infection are highly variable. In some patients, symptoms last for only 3 or 4 days, while in others the symptoms last for months. Higher prevalence of chronic Giardia infection in patients with immunodeficiency supports that the failure to develop an effective immune response against Giardia may account for the chronicity of the infections (O'Handley et al., 2003). In developed countries, the incidence rate peaks at the age of 1-4 years (Flannagan, 1992); a second peak is observed at the 20-40 age groups, partly due to the care for the young children and partly due to travelling (Medema, 1999). The main symptoms include diarrhoea, abdominal pain, nausea, vomiting, flatulence, anorexia and fever (Nash et al., 1987; Farthing, 1996; Katz et al., 2006). In most instances the diarrhoeal illness is short-lived and self-limited. However, a proportion of individuals develop persistent diarrhoea (Farthing, 1996; Katz et al., 2006), sometimes accompanied by malabsorption of sugars and fat and by weight loss. There is evidence that infection with Giardia results in 'failure to thrive' in children, by impairment of the uptake of nutrients (Farthing, 1994; Hall, 1994). A high prevalence of chronice fatigue syndrome has been reported as a post-infection sequel in patients (Naess et al., 2012; Wensaas et al., 2012; Mørch et al., 2013). 
The relation between clinical symptomatology and the Giardia genotype is controversial. In a study in The Netherlands, assemblage A isolates were solely detected in patients with intermittent diarrhoeal complaints, while assemblage B isolates were present in patients with persistent diarrhoeal complaints (Homan and Mank, 2001). A strong correlation between infection with assemblage B and diarrhoea was observed in Saudi children (Al-Mohammed, 2011). An association between assemblage B and flatulence in children was reported by Lebbad et al. (2011). In contrast, Read et al. (2002) found that assemblage B genotypes were more prevalent in asymptomatic children than those of assemblage A and according to Haque et al. $(2005,2009)$ only assemblage A was an important cause of diarrhoea in children in Bangladesh. A systematic review and meta-analysis confirmed that Giardia infections of both assemblages A and B can cause acute or persistent diarrhoea (Muhsen and Levine, 2012).

However, Giardia infections are often asymptomatic. In some studies no significant association between Giardia and diarrhoea was found (Guerrant et al., 1983; Schorling et al., 1990; Hollm-Delgado et al., 2008; Boeke et al., 2010). In both volunteers and outbreak situations, a sizable proportion of the infected subjects are asymptomatic, often exceeding the proportion with manifest clinical illness (Muhsen and Levine, 2012). It has been estimated that between $50 \%$ and $75 \%$ of Giardia-infected persons may be asymptomatic (USEPA, 1998a). Children with asymptomatic Giardia infection serve as unidentified carriers and may be responsible for transmission of the infection. Secondary transmission among family members may occur. Asymptomatic infections may last for months or years (ICAIR, 1984).

\section{Prevalence of Giardia in animals}

In calves younger than six months, the prevalence varies between 17\% (Muhid et al., 2012) and 73\% (Olson et al., 1997) and on farm level it can be as high as 100\% (Olson et al., 1997; Hunt et al., 2000; Geurden et al., $2010,2012)$. In cattle the livestock specific assemblage $\mathrm{E}$ is most prevalent, although up to $59 \%$ zoonotic assemblage A isolates and mixed infection with both $\mathrm{A}$ and $\mathrm{E}$ have been reported (Geurden et al., 2008b; Sprong et al., 2009). This suggests that calves should be considered as a potential reservoir for human infections. However, within assemblage A, sub-assemblage AI is predominantly found in livestock and companion animals, while assemblage AII is more prevalent in humans (Sprong et al., 2009). The prevalence of Giardia in sheep and goats is reported to range from $10 \%$ to $40 \%$ with assemblage E detected in $75 \%$, assemblage A in $27 \%$ and assemblage B in $2 \%$ of cases (Robertson, 2009).

The prevalence of Giardia in pigs ranges from 1\% to 51\% (Armson et al., 2009; Farzan et al., 2011; BuduAmoako et al., 2012). The herd prevalence was $18 \%, 22 \%$ and $84 \%$ for sows, piglets and weaners in Denmark (Maddox-Hyttel et al., 2006) and $12 \%$ in Zambia (Siwila and Mwape et al., 2012). DNA sequencing demonstrated that assemblage E was the most common genotype in Australia and the UK (Armson et al., 2009; Minetti et al., 2013), while in Canada assemblage B was predominant (Farzan et al., 2011). Assemblage A was found in both weaners and piglets in Denmark (Langkjaer et al., 2007) and in pigs in Australia (Armson et al., 2009). Unexpectedly, the canine-specific assemblages $C$ and $D$ and the feline-specific assemblage $F$ were also found occasionally in pigs in different countries (Langkjaer et al., 2007; Armson et al., 2009; Minetti et al., 2013). As for humans, it remains unclear whether the presence of these assemblages represents a patent infection or merely indicates carriage.

The prevalence of Giardia in horses was 1\% in Brazil (De Souza et al., 2009), 9\%-23\% in Italy (Veronesi et al., 2010; Traversa et al., 2012) and 17\% in Colombia (Santín et al., 2013). G. duodenalis isolates from horses belonged predominantly to the zoonotic assemblages A and B (Traub et al., 2005; Traversa et al., 2012; Santín et al., 2013) and to a lesser extent to assemblage E (Veronesi et al., 2010; Traversa et al., 2012).

In dogs, the prevalence of Giardia infections varies from 1\% to 55\% (Itoh et al., 2005; Jafari Shoorijeh et al., 2008). The most prevalent assemblages in dogs are the dog-specific assemblages C and D (Beck et al., 2012) but other sub-assemblages such as AI, AII, BIII and BIV are also detected in dogs worldwide (Souza et al., 2007; Palmer et al., 2008; Claerebout et al., 2009; Sprong et al., 2009), sometimes in higher frequencies than the dogspecific assemblages (e.g. Leonhard et al., 2007; Claerebout et al., 2009; Covacin et al., 2011).

Worldwide the prevalence of Giardia in cats ranges from 1\%-40\% (De Santis-Kerr et al., 2006; Itoh et al., 2006; Gow et al., 2009; Mohsen and Hossein, 2009; Mircean et al., 2011; Sabshin et al., 2012). Assemblage F and sub-assemblage AI are predominant but assemblage D and sub-assemblages AII, AIII were also detected in cats (Papini et al., 2007; Souza et al., 2007; Palmer et al., 2008; Sprong et al., 2009). 


\section{A. Ehsan and Others}

\section{Veterinary importance}

Although $G$. duodenalis is recognised worldwide as the most common parasitic cause of gastrointestinal disorder in human patients, the relevance of infection in production animals is open to debate (Geurden et al., 2010). The clinical signs may vary considerably between animals and animal species due to the involvement in the pathogenesis of giardiosis of both parasite and host factors. This lack of consistency in clinical outcome resulted in the perception that Giardia is not a major cause of clinical disease in ruminants. However, several studies reported clinical signs caused by Giardia both in natural infections (St. Jean, 1987; O'Handley et al., 1999; Aloisio et al., 2006; Geurden et al., 2006b) and in experimental infections (Olson et al., 1995; Geurden et al., 2006a). Infection can result in diarrhoea that does not respond to antibiotic or coccidiostatic treatment. The excretion of pasty to fluid faeces with a mucoid appearance may be indicative for giardiosis, especially when the diarrhoea occurs in young animals.

A study in dairy calves showed that calves did not begin to excrete Giardia cysts until approximately 1 month of age. Passive immunity through colostrum may have the potential to provide initial protection against Giardia infections as colostrum contains a high level of anti-Giardia antibodies. Failure to develop a humoral immune response from natural infections by these calves could account for the high prevalence and chronic duration of the infections (O'Handley et al., 2003).

In pigs, a significant association was found between the presence of assemblage $\mathrm{E}$ and soft to diarrhoeic stool, whereas assemblage A was not correlated with diarrhoea (Armson et al., 2009). This is in contrast to previous studies that have reported no association between Giardia infections in pigs and diarrhoea (Maddox-Hyttel et al., 2006, Hamnes et al., 2007; Langkjaer et al., 2007).Next to diarrhoea, there is an economic impact of giardiosis for farmers. In goat kids and lambs an experimental infection resulted in a decreased feed efficiency and subsequently a decreased weight gain (Olson et al., 1995; Sweeney et al., 2011, 2012). Infections with Giardia in dogs and cats are common. Clinical signs vary from asymptomatic to small bowel diarrhoea and associated discomfort (Fiechter et al., 2012).

\section{REFERENCES}

1. Aloisio F, Filippini G, Antenucci P, Lepri E, Pezzotti G, Cacciò SM and Pozio E (2006). Severe weight loss in lambs infected with Giardia duodenalis assemblage B. Veterinary Parasitology 142: 154-158.

2. Al-Mohammed HI (2011). Genotypes of Giardia intestinalis clinical isolates of gastrointestinal symptomatic and asymptomatic Saudi children. Parasitology Research 108: 1375-1381.

3. Alonso-Fresán MU, García-Alvarez A, Salazar-García F, Vázquez-Chagoyán JC, Pescador-Salas N and SaltijeralOaxaca J (2005). Prevalence of Cryptosporidium spp. in asymptomatic sheep in family flocks from Mexico State. Journal of Veterinary Medicine. B, Inectious Diseases and Veterinary Public Health 52: 482-483.

4. Anderson BC (1987). Abomasal cryptosporidiosis in cattle. Veterinary Pathology 24: 235-238.

5. Angus KW, Tzipori S, Gray EW (1982). Intestinal lesions in specific-pathogen-free lambs associated with a Cryptosporidium from calves with diarrhoea. Veterinary Pathology 19: 67-78.

6. Armson A, Yang R, Thompson J, Johnson J, Reid S and Ryan UM (2009). Giardia genotypes in pigs in Western Australia: prevalence and association with diarrhoea. Experimental Parasitology 121: 381-3.

7. Bajer A, Bednarska M and Rodo A (2011). Risk factors and control of intestinal parasites infections in sled dogs in Poland. Veterinary Parasitology 175: 343-50.

8. Blackburn BG, Craun GF, Yoder JS, Hill V, Calderon RL, Chen N, Lee SH, Levy DA and Beach MJ (2004). Surveillance for waterborne-disease outbreaks associated with drinking water-United States, 2001-2002.MMWR Surveillance Summaries 53: 23-45.

9. Boeke CE, Mora-Plazas M, Forero Y and Villamor E (2010). Intestinal protozoan infections in relation to nutritional status and gastrointestinal morbidity in Colombian school children. Journal of Tropical Paediatrics 56: 299-306.

10. Bouzid M, Hunter PR, Chalmers RM and Tyler KM (2013). Cryptosporidium pathogenicity and virulence. Clinical Microbiology Reviews 26: 115-134.

11. Budu-Amoako E, Greenwood SJ, Dixon BR, Barkema HW, Hurnik D, Estey C and McClure JT (2012). Occurrence of Giardia and Cryptosporidium in pigs on Prince Edward Island, Canada. Veterinary Parasitology 184: $18-24$

12. Burton AJ, Nydam DV, Dearen TK, Mitchell K, Bowman DD and Xiao L (2010). The prevalence of Cryptosporidium, and identification of the Cryptosporidium horse genotype in foals in New York State. Veterinary Parasitology 174: 139-144. 
13. Bushen OY, Kohli A, Pinkerton RC, Dupnik K, Newman RD, Sears CL, Fayer R, Lima AA and Guerrant RL (2007). Heavy cryptosporidial infections in children in northeast Brazil: comparison of Cryptosporidium hominis and Cryptosporidium parvum. Transactions of the Royal Society of Tropical Medicine and Hygiene 1001: 378-384.

14. Cama VA, Ross JM, Crawford S, Kawai V, Chavez-Valdez R, Vargas D, Vivar A, Ticona E, Navincopa M, Williamson J, Ortega Y, Gilman RH, Bern C and Xiao L (2007). Differences in clinical manifestations among Cryptosporidium species and subtypes in HIV-infected persons. Journal of Infectious Diseases 196: 684-691.

15. Cama VA, Bern C, Roberts J, Cabrera L, Sterling CR, Ortega Y, Gilman RH and Xiao L (2008). Cryptosporidium species and subtypes and clinical manifestations in children, Peru. Emerging Infectious Diseases 14: 1567-1574.

16. Casemore DP (1990). Epidemiological aspects of human cryptosporidiosis. Epidemiology and Infection 104:1-28.

17. Chalmers RM, Sturdee AP, Bull SA, Miller A and Wright SE (1997). The prevalence of Cryptosporidium parvum and $C$. Muris in Mus domesticus, Apodemus sylvaticus and Clethrionomys glareolus in an agricultural system. Parasitology Research 83: 478-482.

18. Chalmers RM, Thomas AL, Butler BA and Morel MC (2005). Identification of Cryptosporidium parvum genotype 2 in domestic horses. Veterinary Record 156: 49-50.

19. Chalmers RM, Hadfield SJ, Jackson CJ, Elwin K, Xiao L and Hunter P (2008). Geographic linkage and variation in Cryptosporidium hominis. Emerging Infectious Diseases 14: 496-498.

20. Chalmers RM, Elwin K, Thomas AL, Guy EC and Mason B (2009). Long-term Cryptosporidium typing reveals the aetiology and species-specific epidemiology of human cryptosporidiosis in England and Wales, 2000 to 2003. EuroSurveillance 4: pii: 19086.

21. Chen F and Huang K (2007). Prevalence and phylogenetic analysis of Cryptosporidium in pigs in eastern China. Zoonoses and Public Health 54: 393-400.

22. Chen X, Keithly JS, Paya CV and LaRusso NF (2002). Cryptosporidiosis. The New England Journal of Medicine 346:1723-1731.

23. Chen Z, MI R, Yu H, Shi Y, Huang Y, Chen Y, Zhou P, Cai Y and Lin J (2011). Prevalence of Cryptosporidium spp. in pigs in Shanghai, China. Veterinary Parasitology 181: 113-9.

24. Chermette R and Blondel S (1989). Cryptosporidiose des Carnivores domestiques, resultats preliminairesen France. Bulletin de la Société française de parasitologie 7: 31-36.

25. Claerebout E, Casaert S, Dalemans AC, De Wilde N, Levecke B, Vercruysse J and Geurden T (2009). Giardia and other intestinal parasites in different dog populations in Northern Belgium. Veterinary Parasitology 161: 41-6.

26. Current WL and Garcia LS (1991). Cryptosporidiosis. Clinical Microbiology Reviews 4: 325-258.

27. de Graaf DC, Vanopdenbosch E, Ortega-Mora LM, Abbassi H and Peeters JE (1999). A review of the importance of cryptosporidiosis in farm animals. International Journal of Parasitology 29: 1269-1287.

28. de la Fé Rodríguez PY, Martin LO, Muñoz EC, Imberechts H, Butaye P, Goddeeris BM and Cox E (2013). Several enteropathogens are circulating in suckling and newly weaned piglets suffering from diarrhoea in the province of Villa Clara, Cuba. Tropical Animal Health and Production 45: 435-440.

29. De Santis-Kerr AC, Raghavan M, Glickman NW, Caldanaro RJ, Moore GE, Lewis HB, Schantz PM and Glickman LT (2006). Prevalence and risk factors for Giardia and coccidia species of pet cats in 2003-2004. Journal Feline Medicine and Surgery 8: 292-301.

30. De Souza PN, Bomfim TC, Huber F, Abboud LC and Gomes RS (2009). Natural infection by Cryptosporidium sp.; Giardia sp. and Eimeria leuckarti in three groups of equines with different handlings in Rio de Janeiro, Brazil. Veterinary Parasitology 160: 327-333.

31. Díaz P, Quílez J, Robinson G, Chalmers RM, Díez-Baños P and Morrondo P (2010). Identification of Cryptosporidium xiaoi in diarrhoeic goat kids (Capra hircus) in Spain. Veterinary Parasitology 172: 132-134.

32. Diaz V, Campos M, Lozano J, Manas I and Gonzalez J (1996). Aspects of animal giardiasis in Granada province (southern Spain). Veterinary Parasitology 64: 171-176.

33. Dieter RA, Jr. Dieter RS, Dieter RA and $3^{\text {rd }}$. Gulliver G (2001). Zoonotic diseases: health aspects of Canadian geese. International Journal of Circumpolar Health 60: 676-684.

34. Enemark HL, Ahrens P, Bille-Hansen V, Heegaard PM, Vigre H, Thamsborg SM and Lind P (2003). Cryptosporidium parvum: infectivity and pathogenicity of the 'porcine' genotype. Parasitology 126: 407-416.

35. Ellis AE, Brown CA and Miller DL (2010). Diagnostic exercise: chronic vomiting in a dog. Veterinary Pathology 47: 991-993.

36. Elwin K, Hadfield SJ, Robinson G, Crouch ND and Chalmers RM (2012). Cryptosporidium viatorum n. sp. (Apicomplexa: Cryptosporidiidae) among travellers returning to Great Britain from the Indian subcontinent, 20072011. International Journal for Parasitology 42: 675-682. 


\section{A. Ehsan and Others}

37. Esteban E and Anderson BC (1995). Cryptosporidium muris: prevalence, persistency, and detrimental effect on milk production in a dry lot dairy. Journal of Dairy Science 78: 1068-1072.

38. Farthing MJG (1994). Giardiasis as a disease. In: Thompson RCA, Reynoldson JA, Lymbery AJ (eds.). Giardia from molecules to disease, CAB Int.; Wallingford, UK. pp. 15-37.

39. Farthing MJG (1996). Giardiasis. Gastroenterology Clinics of North America 25: 493- 515.

40. Farzan A, Parrington L, Coklin T, Cook A, Pintar K, Pollari F, Friendship R, Farber J and Dixon B (2011). Detection and characterization of Giardia duodenalis and Cryptosporidium spp. on swine farms in Ontario, Canada. Foodborne Pathogens and Disease 8: 1207-1213.

41. Fayer R (2008). Biology. In: Fayer, R.; Xiao, L. (Eds.), Cryptosporidium and Cryptosporidiosis, second ed. CRC Press and IWA Publishing, Boca Raton, FL, pp. 1-42.

42. Fayer R, Santín M and Trout JM (2007). Prevalence of Cryptosporidium species and genotypes in mature dairy cattle on farms in eastern United States compared with younger cattle from the same locations. Veterinary Parasitology 145: 260-266.

43. Fayer R, Santín M, Trout JM and Dubey JP (2006c). Detection of Cryptosporidium felis and Giardia duodenalis Assemblage $\mathrm{F}$ in a cat colony. Veterinary Parasitology 140: 44-53.

44. Fayer R, Santín M, Trout JM and Greiner E (2006b). Prevalence of species and genotypes of Cryptosporidium found in 1-2-year-old dairy cattle in the eastern United States. Veterinary Parasitology 135: 105-12.

45. Feltus DC, Giddings CW, Schneck BL, Monson T, Warshauer D and McEvoy JM (2006). Evidence supporting zoonotic transmission of Cryptosporidium spp. In Wisconsin. Journal of Clinical Microbiology 44: 4303-4308.

46. Fiechter R, Deplazes P and Schnyder M (2012). Control of Giardia infections with ronidazole and intensive hygiene management in a dog kennel. Veterinary Parasitology 187: 93-98.

47. FitzGerald L, Bennett M, Ng J, Nicholls P, James F, Elliot A, Slaven M and Ryan U (2011). Morphological and molecular characterization of a mixed Cryptosporidium muris/Cryptosporidium felis infection in a cat. Veterinary Parasitology 175: 160-164.

48. Flannagan PA (1992). Giardia - Diagnosis, clinical course and epidemiology - A review. Epidemiology and Infection 109: 1-22.

49. Foronda P, Bargues MD, Abreu-Acosta N, Periago MV, Valero MA, Valladares B and Mas-Coma S (2008). Identification of genotypes of Giardia intestinalis of human isolates in Egypt. Parasitology Research 103: 11771181 .

50. Gelanew T, Lalle M, Hailu A, Pozio E and Cacciò SM (2007). Molecular characterization of human isolates of Giardia duodenalis from Ethiopia. Acta Tropica 102: 92-99.

51. Geurden T, Claerebout E, Dursin L, Deflandre A, Bernay F, Kaltsatos V and Vercruysse J (2006a). The efficacy of an oral treatment with paromomycin against an experimental infection with Giardia in calves. Veterinary Parasitology 135: 241-247.

52. Geurden T, Vercruysse J and Claerebout E (2006b). Field testing of a fenbendazole treatment combined with hygienic and management measures against a natural Giardia infection in calves. Veterinary Parasitology 142: 367-371.

53. Geurden T, Thomas P, Casaert S, Vercruysse J and Claerebout E (2008). Prevalence and molecular characterisation of Cryptosporidium and Giardia in lambs and goat kids in Belgium. Veterinary Parasitology 155: 142-145.

54. Geurden T, Geldhof P, Levecke B, Martens C, Berkvens D, Casaert S, Vercruysse J and Claerebout E (2008). Mixed Giardia duodenalis assemblage A and E infections in calves. International Journal for Parasitology 38: 259-264.

55. Geurden T, Levecke B, Cacció SM, Visser A, De Groote G, Casaert S, Vercruysse J and Claerebout E (2009). Multilocus genotyping of Cryptosporidium and Giardia in non-outbreak related cases of diarrhoea in human patients in Belgium. Parasitology 36: 1161-1168.

56. Geurden T, Vercruysse J and Claerebout E (2010). Is Giardia a significant pathogen in production animals? Experimental Parasitology 124: 98-106.

57. Geurden T, Vanderstichel R, Pohle H, Ehsan A, von Samson-Himmelstjerna G, Morgan ER, Camuset P, Capelli G, Vercruysse J and Claerebout E (2012). A multicentre prevalence study in Europe on Giardia duodenalis in calves, with molecular identification and risk factor analysis. Veterinary Parasitology 190: 383-390.

58. Giangaspero A, Iorio R, Paoletti B, Traversa D and Capelli G (2006). Molecular evidence for Cryptosporidium infection in dogs in Central Italy. Parasitology Research 99: 297-299.

59. Goma FY, Geurden T, Siwila J, Phiri IGK, Gabriel S, Claerebout E and Vercruysse J (2007). The prevalence and molecular characterisation of Cryptosporidium spp. in small ruminants in Zambia. Small Ruminant Research 22: 77-80. 
60. Goodwin MA and Barsanti JA (1990). Intractable diarrhoea associated with intestinal cryptosporidiosis in a domestic cat also infected with feline leukaemia virus. Journal of the American Veterinary Medical Association 26: 365-368

61. Gow AG, Gow DJ, Hall EJ, Langton D, Clarke C and Papasouliotis K (2009). Prevalence of potentially pathogenic enteric organisms in clinically healthy kittens in the UK. Journal Feline Medicine and Surgery 11: 655-62.

62. Grimason AM, Smith HV, Parker JF, Jackson MH, Smith PG and Girdwood RW (1993). Occurrence of Giardia spp. cysts and Cryptosporidium sp oocysts in faeces from public parks in the west of Scotland. Epidemiology and Infection 110: 641-645.

63. Grinberg A, Oliver L, Learmonth JJ, Leyland M, Roe W and Pomroy WE (2003). Identification of Cryptosporidium parvum "cattle" genotype from a severe outbreak of neonatal foal diarrhoea. Veterinary Record 153: 628-631.

64. Grinberg A, Learmonth J, Kwan E, Pomroy W, Lopez Villalobos N, Gibson I and Widmer G (2008). Genetic diversity and zoonotic potential of Cryptosporidium parvum causing foal diarrhoea. Journal of Clinical Microbiology 46: 2396-2398.

65. Grinberg A, Pomroy WE, Carslake HB, Shi Y, Gibson IR and Drayton BM (2009). A study of neonatal cryptosporidiosis of foals in New Zealand. New Zealand Veterinary Journal 57: 284-289.

66. Guerrant RL (1997). Cryptosporidiosis: an emerging, highly infectious threat. Emerging Infectious Diseases 3:5157.

67. Guerrant RL, Kirchhoff LV, Shields DS, Nations MK, Leslie J, de Sousa MA, Araujo JG, Correia LL, Sauer KT, McClelland KE, Trowbridge FL and Hughes JM (1983). Prospective study of diarrheal illnesses in northeastern Brazil: patterns of disease, nutritional impact, etiologies, and risk factors. Journal of Infectious Diseases 148: 986997.

68. Hajdušek O, Ditrich O and Slapeta J (2004). Molecular identification of Cryptosporidium spp. in animal and human hosts from the Czech Republic. Veterinary Parasitology 122: 183-192.

69. Hall A (1994). Giardia infections: epidemiology and nutritional consequences. In: Thompson RCA, Reynoldson JA, Lymbery AJ (eds.). Giardia from molecules to disease, CAB Int.; Wallingford, UK. pp. 251-279.

70. Hamnes IS, Gjerde BK, Forberg T and Robertson LJ (2007). Occurrence of Cryptosporidium and Giardia in suckling piglets in Norway. Veterinary Parasitology 144: 222-233.

71. Haque R, Mondal D, Kirkpatrick BD, Akther S, Farr BM, Sack RB, Petri WAJr (2003). Epidemiologic and clinical characteristics of acute diarrhea with emphasis on Entamoeba histolytica infections in preschool children in an urban slum of Dhaka, Bangladesh. The American Journal of Tropical Medicine and Hygiene 69: 398-405.

72. Haque R, Roy S, Kabir M, Stroup SE, Mondal D and Houpt ER (2005). Giardia assemblage A infection and diarrhea in Bangladesh. Journal of Infectious Diseases 192: 2171-2173.

73. Haque R, Mondal D, Karim A, Molla IH, Rahim A, Faruque ASG, Ahmad N, Kirkpatrick BD, Houpt E, Snider C, Petri WA Jr (2009). Prospective case-control study of the association between common enteric protozoal parasites and diarrhea in Bangladesh. Clinical Infectious Diseases 48:1191-1197.

74. Hollm-Delgado MG, Gilman RH, Bern C, Cabrera L, Sterling CR, Black RE and Checkley W (2008). Lack of an adverse effect of Giardia intestinalis infection on the health of Peruvian children. American Journal of Epidemiology 168: 647-55.

75. Homan WL and Mank TG (2001). Human giardiosis: genotype linked differences in clinical symptomatology. International Journal for Parasitology 31: 822-826.

76. Hoopes JH, Polley L, Wagner B and Jenkins EJ (2013). A retrospective investigation of feline gastrointestinal parasites in western Canada. Canadian Veterinary Journal 54: 359-362.

77. Hunt CL, Ionas G and Brown TJ (2000). Prevalence and strain differentiation of Giardia intestinalis in calves in the Manawatu and Waikato regions of North Island, New Zealand. Veterinary Parasitology 91: 7-13.

78. Hunter PR, Hughes S, Woodhouse S, Syed Q, Verlander NQ, Chalmers RM, Morgan K, Nichols G, Beeching N and Osborn K (2004). Sporadic cryptosporidiosis case-control study with genotyping. Emerging Infectious Diseases 10: 1241-1249.

79. Hunter P and Nichols G (2002). Epidemiology and clinical features of Cryptosporidium infection in immunocompromised patients. Clinical Microbiology Reviews 15: 145-154.

80. ICAIR Life Systems Inc (1984). Criteria Document on Giardia, U.S. EPA, Washington, DC.

81. Irwin PJ (2002). Companion animal parasitology: a clinical perspective. International Journal for Parasitology 32:581-593.

82. Islam A (1990). Giardiasis in developing countries. In: Meyer EA (ed). Human Parasitic Diseases, Vol. 3, Giardiasis. Elsevier Science Publ.; Amsterdam, the Netherlands, pp. 235-266. 


\section{A. Ehsan and Others}

83. Itoh N, Muraoka N, Saeki H, Aoki M and Itagaki T (2005). Prevalence of Giardia intestinalis infection in dogs of breeding kennels in Japan. Journal of Veterinary Medical Science 67: 717-718.

84. Itoh N, Muraoka N, Kawamata J, Aoki M and Itagaki T (2006). Prevalence of Giardia intestinalis infection in household cats of Tohoku district in Japan. Journal of Veterinary Medical Science 68: 161-163.

85. Jafari Shoorijeh S, Sadjjadi SM, Asheri A and Eraghi K (2008). Giardia spp. and Sarcocystis spp. status in pet dogs of Shiraz, Southern part of Iran. Tropical Biomedicine 25: 154-159.

86. Johnson EH, Muirhead DE, Windsor JJ, King GJ, Al-Busaidy R and Cornelius R (1999). Atypical outbreak of caprine cryptosporidiosis in the Sultanate of Oman. Veterinary Record 145: 521-524.

87. Johnson J, Buddle R, Reid S, Armson A and Ryan UM (2008). Prevalence of Cryptosporidium genotypes in pre and post-weaned pigs in Australia. Experimental Parasitology 119: 418-421.

88. Juranek D (1995). Cryptosporidiosis: sources of infection and guidelines for prevention. Clinical Infectious Diseases 22: S57-S61.

89. Katz DE, Heisey-Grove D, Beach M, Dicker RC and Matyas BT (2006). Prolonged outbreak of giardiasis with two modes of transmission. Epidemiology and Infection 134: 935-941.

90. Kváč M, Hanzlikova D, Sak B and Kvetonová D (2009). Prevalence and age-related infection of Cryptosporidium suis, C. muris and Cryptosporidium pig genotype II in pigs on a farm complex in the Czech Republic. Veterinary Parasitology 160: 319-322.

91. Kváč M, Kestřánová M, Květoňová D, Kotková M, Ortega Y, McEvoy J and Sak B (2012). Cryptosporidium tyzzeri and Cryptosporidium muris originated from wild West-European house mice (Mus musculus domesticus) and East-European house mice (Mus musculus musculus) are non-infectious for pigs. Experimental Parasitology 131: 107-10.

92. Kváč M, Kouba M and Vítovec J (2006). Age-related and housing-dependence of Cryptosporidium infection of calves from dairy and beef herds in South Bohemia, Czech Republic. Veterinary Parasitology 137: 202-209.

93. Kváč M, Sak B, Kvetonová D, Ditrich O, Hofmannová L, Modry D, Vítovec J and Xiao L (2008). Infectivity, pathogenicity, and genetic characteristics of mammalian gastric Cryptosporidium spp. in domestic ruminants. Veterinary Parasitology 153: 363-367.

94. Kváč M and Vítovec J (2003). Prevalence and pathogenicity of Cryptosporidium andersoni in one herd of beef cattle. Journal of Veterinary Medicine. B. Infectious Diseases and Veterinary Public health 50: 451-457.

95. Laatamna AE, Wagnerová P, Sak B, Květoňová D, Aissi M, Rost M and Kváč M (2013). Equine cryptosporidial infection associated with Cryptosporidium hedgehog genotype in Algeria. Veterinary Parasitology pii: S03044017(13)00276-8.

96. Langkjaer RB, Vigre H, Enemark HL and Maddox-Hyttel C (2007). Molecular and phylogenetic characterization of Cryptosporidium and Giardia from pigs and cattle in Denmark. Parasitology 134: 339-350.

97. Learmonth JJ, Ionas G, Pita AB and Cowie RS (2003). Identification and genetic characterisation of Giardia and Cryptosporidium strains in humans and dairy cattle in the Waikato Region of New Zealand. Water Science Technology 47: 21-26.

98. Learmonth JJ, Ionas G, Ebbett KA and Kwan ES (2004). Genetic characterization and transmission cycles of Cryptosporidium species isolated from humans in New Zealand. Applied and Environmental Microbiology 70:3973-3978.

99. Leonhard S, Pfister K, Beelitz P, Wielinga C and Thompson RC (2007). The molecular characterisation of Giardia from dogs in southern Germany. Veterinary Parasitology 150: 33-38.

100. Lent SF, Burkhardt JE and Bolka D (1993). Coincident enteric cryptosporidiosis and lymphosarcoma in a cat with diarrhoea. Journal of the American Veterinary Medical Association 29: 492-496.

101. Leoni F, Amar C, Nichols G, Pedraza-Diaz S and McLauchlin J (2006). Genetic analysis of Cryptosporidium from 2414 humans with diarrhoea in England between 1985 and 2000. Journal of Medical Microbiology 55: 703-707.

102. Lucio-Forster A, Griffiths JK, Cama VA, Xiao L and Bowman DD (2010). Minimal zoonotic risk of cryptosporidiosis from pet dogs and cats. Trends in Parasitology 26: 174-179.

103. Lupo PJ, Langer-Curry RC, Robinson M, Okhuysen PC and Chappell CL (2008). Cryptosporidium muris in a Texas canine population. The American Journal of Tropical Medicine and Hygiene 78: 917-921.

104. Maddox-Hyttel C, Langkjaer RB, Enemark HL and Vigre H (2006). Cryptosporidium and Giardia in different age groups of Danish cattle and pigs--occurrence and management associated risk factors. Veterinary Parasitology 141: 48-59.

105. Majewska AC, Solarczyk P, Tamang L and Graczyk TK (2004). Equine Cryptosporidium parvum infections in western Poland. Parasitology Research 93:274-178. 
106. Manabe YC, Clark DP, Moore RD, Lumadue JA, Dahlman HR, Belitsos PC, Chaisson RE and Sears CL (1998). Cryptosporidiosis in patients with AIDS: correlates of disease and survival. Clinical Infectious Diseases 27: 536542.

107. McLauchlin J, Amar C, Pedraza-Diaz S and Nichols GL (2000). Molecular epidemiological analysis of Cryptosporidium spp. in the United Kingdom: results of genotyping Cryptosporidium spp. in 1,705 fecal samples from humans and 105 fecal samples from livestock animals. Journal of Clinical Microbiology 38: 3984-3990.

108. Medema GJ (1999). Cryptosporidium and Giardia: new challenges to the water industry. Thesis Universiteit Utrecht. igiturarchive.library.uu.nl/dissertations/1883822/full.pdf.

109. Meireles MV (2010). Cryptosporidium infection in Brazil: implications for veterinary medicine and public health. Revista Brasileira de Parasitologia Veterinária 19: 197-204.

110. Miller DL, Liggett A, Radi ZA and Branch LO (2003). Gastrointestinal cryptosporidiosis in a puppy. Veterinary Parasitology 115: 199-204.

111. Minetti C, Taweenan W, Hogg R, Featherstone C, Randle N, Latham SM and Wastling JM (2013). Occurrence and diversity of Giardia duodenalis assemblages in livestock in the UK. Transboundary and Emerging Diseases 61: e60-7.

112. Mircean V, Györke A, Jarca A and Cozma V (2011). Prevalence of Giardia species in stool samples by ELISA in household cats from Romania and risk factors. Journal of Feline Medicine and Surgery 13: 479-482.

113. Mohsen A and Hossein H (2009). Gastrointestinal parasites of stray cats in Kashan, Iran. Tropical Biomedicine 26: $16-22$.

114. Mørch K, Hanevik K, Rivenes AC, Bødtker JE, Næss H, Stubhaug B, Wensaas KA, Rortveit G, Eide GE, Hausken $\mathrm{T}$ and Langeland $\mathrm{N}$ (2013). Chronic fatigue syndrome 5 years after giardiasis: differential diagnoses, characteristics and natural course. BMC Gastroenterology 13: 28.

115. Morgan UM, Sargent KD, Desplazes P, Forbes DA, Spano F, Hertzberg H, Elliot A and Thompson RCA (1998). Molecular characterization of Cryptosporidium from various hosts. Parasitology 117: 31-37.

116. Mtambo MM, Nash AS, Blewett DA, Smith HV and Wright S (1991). Cryptosporidium infection in cats: prevalence of infection in domestic and feral cats in the Glasgow area. Veterinary Record 129: 502-504.

117. Mueller-Doblies D, Giles M, Elwin K, Smith RP, Clifton-Hadley FA and Chalmers RM (2008). Distribution of Cryptosporidium species in sheep in the UK. Veterinary Parasitology 154: 214-219.

118. Muhid A, Robertson I, Ng J, Yang R and Ryan U (2012). Prevalence of Giardia spp. infection in pre-weaned and weaned calves in relation to management factors. Veterinary Journal 191: 135-137.

119. Muhsen K and Levine MM (2012). A systematic review and meta-analysis of the association between Giardia lamblia and endemic pediatric diarrhea in developing countries. Clinical Infectious Diseases 55: S271-93.

120. Naess H, Nyland M, Hausken T, Follestad I and Nyland HI (2012). Chronic fatigue syndrome after Giardia enteritis: clinical characteristics, disability and long-term sickness absence. BMC Gastroenterology 12: 13.

121. Nash TE, Herrington DA, Losonsky GA and Levine MM (1987). Experimental human infections with Giardia lamblia. Journal of Infectious Diseases 156: 974-984.

122. Nash AS, Mtambo MMA and Gibbs HA (1993). Cryptosporidium infection in farm cats in the Glasgow area. Veterinary Record 133: 576-577.

123. Němejc K, Sak B, Květoňová D, Kernerová N, Rost M, Cama VA and Kváč M (2013). Occurrence of Cryptosporidium suis and Cryptosporidium scrofarum on commercial swine farms in the Czech Republic and its associations with age and husbandry practices. Parasitology Research 112: 1143-1154.

124. O'Donoghue P (1995). Cryptosporidium and cryptosporidiosis in man and animals. International Journal for Parasitology 25:139-195.

125. O'Handley RM, Cockwill C, McAllister TA, Jelinski M, Morck DW and Olson ME (1999). Duration of naturally acquired giardiosis and cryptosporidiosis in dairy calves and their association with diarrhea. Journal of the American Veterinary Medical Association 214: 391-396.

126. O'Handley RM, Ceri H, Anette C and Olson ME (2003). Passive immunity and serological immune response in dairy calves associated with natural Giardia duodenalis infections. Veterinary Parasitology 113: 89-98.

127. Olson ME, McAllister TA, Deselliers L, Morck DW, Cheng KJ, Buret AG and Ceri H (1995). Effects of Giardiasis on production in a domestic ruminant (lamb) model. American Journal of Veterinary Research 56: 1470-1474.

128. Olson ME, Guselle NJ, O'Handley RM, Swift ML, McAllister TA, Jelinski MD and Morck DW (1997). Giardia and Cryptosporidium in dairy calves in British Columbia. Canadian Veterinary Journal 38: 703-706.

129. Olson ME, O'Handley RM, Ralston BJ, McAllister TA and Thompson RC (2004). Update on Cryptosporidium and Giardia infections in cattle. Trends in Parasitology 20: 185-191. 


\section{A. Ehsan and Others}

130. Palmer CS, Traub RJ, Robertson ID, Devlin G, Rees R and Thompson RC (2008). Determining the zoonotic significance of Giardia and Cryptosporidium in Australian dogs and cats. Veterinary Parasitology 154: 142-147.

131. Papini R, Cardini G, Paoletti B and Giangaspero A (2007). Detection of Giardia assemblage A in cats in Florence, Italy. Parasitology Research 100: 653-656.

132. Paraud C, Pors I and Chartier C (2010). Evaluation of oral tilmicosin efficacy against severe cryptosporidiosis in neonatal kids under field conditions. Veterinary Parasitology 170: 149-152.

133. Pirestani M, Sadraei J, Dalimi Asl A, Zavvar M and Vaeznia H (2008). Molecular characterization of Cryptosporidium isolates from human and bovine using 18s rRNA gene in Shahriar county of Tehran, Iran. Parasitology Research 103: 467- 472.

134. Pritchard GC, Marshall JA, Giles M, Chalmers RM and Marshall RN (2007). Cryptosporidium parvum infection in orphan lambs on a farm open to the public. Veterinary Record 161: 11-14.

135. Pritchard GC, Marshall JA, Giles M, Mueller-Doblies D, Sayers AR, Marshall RN, Elwin K and Chalmers RM (2008). Cryptosporidium species in lambs submitted for diagnostic post-mortem examination in England and Wales. Veterinary Record 163: 688-689.

136. Quílez J, Sánchez-Acedo C, del Cacho E, Clavel A and Causapé AC (1996). Prevalence of Cryptosporidium and Giardia infections in cattle in Aragón (northeastern Spain). Veterinary Parasitology 66: 139-46.

137. Quílez J, Torres E, Chalmers RM, Hadfield SJ, Del Cacho E and Sanchez-Acedo C (2008). Genotype and subtype characterization of Cryptosporidium in lambs and goat kids in Spain. Applied and Environmental Microbiology 74: 6026-6031.

138. Rabbani GH and Islam A (1994). Giardiasis in humans: populations most at risk and prospects for control. In: Thompson RCA, Reynoldson JA and Lymbery AJ (eds.). Giardia from molecules to disease, CAB Int.; Wallingford, UK. pp. 217-249.

139. Ralston BJ, Cockwill C, Guselle N, Van Herk FH, McAllister TA and Olson ME (2003). Prevalence of Giardia and Cryptosporidium andersoni and their effect on performance in feedlot beef calves. Canadian Journal of Animal Science 83: 153-159.

140. Rambozzi L, Menzano A, Mannelli A, Romano S and Isaia MC (2007). Prevalence of cryptosporidian infection in cats in Turin and analysis of risk factors. Journal of Feline Medicine and Surgery 9: 392-396.

141. Read C, Walters J, Robertson ID and Thompson RC (2002). Correlation between genotype of Giardia duodenalis and diarrhea. International Journal for Parasitology 32: 229-231.

142. Robertson L (2009). Giardia and Cryptosporidium infections in sheep and goats: a review of the potential for transmission to humans via environmental contamination. Epidemiology and Infection 137: 913-921.

143. Ryan U, Xiao L, Read C, Zhou L, Lal AA and Pavlasek I (2003). Identification of novel Cryptosporidium genotypes from the Czech Republic. Applied and Environmental Microbiology 69: 4302-4307.

144. Ryan UM, Bath C, Robertson I, Read C, Elliot A, McInnes L, Traub R and Besier B (2005). Sheep may not be an important zoonotic reservoir for Cryptosporidium and Giardia parasites. Applied and Environmental Microbiology 71: 4992-4997.

145. Sabshin SJ, Levy JK, Tupler T, Tucker SJ, Greiner EC and Leutenegger CM (2012). Enteropathogens identified in cats entering a Florida animal shelter with normal faeces or diarrhea. Journal of the American Veterinary Medical Association 241: 331-337.

146. Santín M (2013). Clinical and subclinical infections with Cryptosporidium in animals. New Zealand Veterinary Journal 61: 1-10.

147. Santín M, Trout JM, Xiao L, Zhou L, Greiner E and Fayer R (2004). Prevalence and age related variation of Cryptosporidium species and genotypes in dairy calves. Veterinary Parasitology 122: 103-117.

148. Santín M, Trout JM and Fayer R (2007). Prevalence and molecular characterization of Cryptosporidium and Giardia species and genotypes in sheep in Maryland. Veterinary Parasitology 146: 1724.

149. Santín M and Trout JM (2008). Companion animals. In: Fayer R, Xiao L (eds). Cryptosporidium and Cryptosporidiosis. CRC Press, Boca Raton,FL, USA. Pp. 437-450.

150. Santín M, Trout JM and Fayer R (2008). A longitudinal study of cryptosporidiosis in dairy cattle from birth to 2 years of age. Veterinary Parasitology 155:15-23.

151. Santín M, Cortés Vecino JA and Fayer R (2013). A large scale molecular study of Giardia duodenalis in horses from Colombia. Veterinary Parasitology 196: 31-36.

152. Sari B, Arslan MO, Gicik Y, Kara M and Taşçi GT (2009). The prevalence of Cryptosporidium species in diarrhoeic lambs in Kars province and potential risk factors. Tropical Animal Health and Production 41: 819-826.

153. Savioli L, Smith H and Thompson A (2006). Giardia and Cryptosporidium join the 'Neglected Diseases Initiative'. Trends in Parasitology 22: 203-208. 
154. Schnyder M, Kohler L, Hemphill A and Deplazes P (2009). Prophylactic and therapeutic efficacy of nitazoxanide against Cryptosporidium parvum in experimentally challenged neonatal calves. Veterinary Parasitology 160: 149154.

155. Schorling JB, Wanke CA, Schorling SK, McAuliffe JF, de Souza MA and Guerrant RL (1990). A prospective study of persistent diarrhea among children in an urban Brazilian slum. Patterns of occurrence and etiologic agents. American Journal of Epidemiology 132: 144-156.

156. Scorza AV, Duncan C, Miles L and Lappin MR (2011). Prevalence of selected zoonotic and vector-borne agents in dogs and cats in Costa Rica. Veterinary Parasitology 183: 178- 83.

157. Sevinç F, Şımşek A and Uslu U (2005). Massive Cryptosporidium parvum infection associated with an outbreak of diarrhoea in neonatal goat kids. Turkish Journal of Veterinary and Animal Sciences 29: 1317-20.

158. Shirley DAT, Moonah SN and Kotloff KL (2012). Burden of disease from Cryptosporidiosis. Current Opinion of Infectious Diseases 25: 555-563.

159. Siwila J and Mwape KE (2012). Prevalence of Cryptosporidium spp. and Giardia duodenalis in pigs in Lusaka, Zambia. Onderstepoort Journal of Veterinary Research 79: E1-5.

160. Sotiriadou I, Pantchev N, Gassmann D and Karanis P (2013). Molecular identification of Giardia and Cryptosporidium from dogs and cats. Parasite 20: 8.

161. Souza SL, Gennari SM, Richtzenhain LJ, Pena HF, Funada MR, Cortez A, Gregori F and Soares RM (2007). Molecular identification of Giardia duodenalis isolates from humans, dogs, cats and cattle from the state of Sao Paulo, Brazil, by sequence analysis of fragments of glutamate dehydrogenase (GDH) coding gene. Veterinary Parasitology 149: 258-264.

162. Sprong H, Cacciò SM, van der Giessen JW, ZOOPNET network and partners (2009). Identification of zoonotic genotypes of Giardia duodenalis. PLoS Neglected Tropical Diseases 3: e558.

163. St Jean G (1987). Diagnosis of Giardia infection in 14 calves. Journal of the American Veterinary Medical Association 191: 831-832.

164. Sturdee AP, Bodley-Tickell AT, Archer A and Chalmers RM (2003). Long-term study of Cryptosporidium prevalence on lowland farm in the United Kingdom. Veterinary Parasitology 116: 97-113.

165. Sulaiman IM, Hira PR, Zhou L, Al-Ali FM, Al-Shelahi FA, Shweiki HM, Iqbal J, Khalid N and Xiao L (2005). Unique endemicity of cryptosporidiosis in children in Kuwait. Journal of Clinical Microbiology 43: 2805-2809.

166. Sweeny JP, Ryan UM, Robertson ID and Jacobson C (2011). Cryptosporidium and Giardia associated with reduced lamb carcass productivity. Veterinary Parasitology 182: 127-139.

167. Sweeny JP, Robertson ID, Ryan UM, Jacobson C and Woodgate RG (2012). Impacts of naturally acquired protozoa and strongylid nematode infections on growth and faecal attributes in lambs. Veterinary Parasitology 184: 298-308

168. Traub R, Wade S, Read C, Thompson A and Mohammed H (2005). Molecular characterization of potentially zoonotic isolates of Giardia duodenalis in horses. Veterinary Parasitology 130: 317-21.

169. Traversa D, Otranto D, Milillo P, Latrofa MS, Giangaspero A, Di Cesare A and Paoletti B (2012). Giardia duodenalis sub-Assemblage of animal and human origin in horses. Infection Genetics and Evolution 12: 16421646.

170. Tumwine JK, Kekitiinwa A, Nabukeera N, Akiyoshi DE, Rich SM, Widmer G, Feng X and Tzipori S (2003). Cryptosporidium parvum in children with diarrhea in Mulago Hospital, Kampala, Uganda. The American Journal of Tropical Medicine and Hygiene 68: 710-715.

171. Tzanidakis N, Sotiraki S, Claerebout E, Ehsan A, Voutzourakis N, Kostopoulou D, Casaert S, Vercruysse J and Geurden T (2014). Occurrence and molecular characterization of Giardia duodenalis and Cryptosporidium spp. in sheep and goats reared under dairy husbandry systems in Greece. Parasite 21: 45. doi: 10.1051/parasite/2014048.

172. USEPA (1998). Drinking water criteria document on Giardia. Environmental Protection Agency, Washington, DC.

173. Uehlinger FD, Greenwood SJ, McClure JT, Conboy G, O'Handley R and Barkema HW (2013). Zoonotic potential of Giardia duodenalis and Cryptosporidium spp. and prevalence of intestinal parasites in young dogs from different populations on Prince Edward Island, Canada. Veterinary Parasitology 196: 509-514.

174. Veronesi F, Passamonti F, Cacciò S, Diaferia M and Piergili Fioretti D (2010). Epidemiological survey on equine Cryptosporidium and Giardia infections in Italy and molecular characterization of isolates. Zoonoses Public Health 57: 510-517.

175. Vieira LS, Silva MB, Tolentino AC, Lima JD and Silva AC (1997). Outbreak of cryptosporidiosis in dairy goats in Brazil. Veterinary Record 140: 427-428. 


\section{A. Ehsan and Others}

176. Vítovec J, Hamadejová K, Landová L, Kváč M, Kvetonová D and Sak B (2006). Prevalence and pathogenicity of Cryptosporidium suis in pre- and post-weaned pigs. Journal of Veterinary Medicine. B, Infectious Diseases and Veterinary Public health 53: 239-243.

177. Wang Y, Feng Y, Cui B, Jian F, Ning C, Wang R, Zhang L and Xiao L (2010). Cervine genotype is the major Cryptosporidium genotype in sheep in China. Parasitology Research 106: 341-347.

178. Wensaas KA, Langeland N, Hanevik K, Mørch K, Eide GE and Rortveit G (2012). Irritable bowel syndrome and chronic fatigue 3 years after acute giardiasis: historic cohort study. Gut 61: 214-219.

179. Wielinga PR, de Vries A, van der Goot TH, Mank T, Mars MH, Kortbeek LM and van der Giessen JW (2008). Molecular epidemiology of Cryptosporidium in humans and cattle in the Netherlands. International Journal for Parasitology 38: 809-817.

180. Xiao L (2010). Molecular epidemiology of cryptosporidiosis: an update. Experimental Parasitology 124: 80-89.

181. Xiao L and Fayer R (2008). Molecular characterization of species and genotypes of Cryptosporidium and Giardia and assessment of zoonotic transmission. International Journal for Parasitology 38: 1239-1255.

182. Xiao L and Feng Y (2008). Zoonotic cryptosporidiosis. FEMS Immunology and Medical Microbiology 52: 309 323.

183. Yang R, Jacobson C, Gordon C and Ryan U (2009). Prevalence and molecular characterisation of Cryptosporidium and Giardia species in pre-weaned sheep in Australia. Veterinary Parasitology 161: 19-24.

184. Yin JH, Yuan ZY, Cai HX, Shen YJ, Jiang YY, Zhang J, Wang YJ and Cao JP (2013). Age-related infection with Cryptosporidium species and genotype in pigs in China. Biomedical and Environmental Sciences 26: 492-495.

185. Yoshiuchi R, Matsubayashi M, Kimata I, Furuya M, Tani H and Sasai K (2010). Survey and molecular characterization of Cryptosporidium and Giardia spp. in owned companion animal, dogs and cats, in Japan. Veterinary Parasitology 174: 313-316.

186. Zhang W, Yang F, Liu A, Wang R, Zhang L, Shen Y, Cao J and Ling H (2013). Prevalence and genetic characterizations of Cryptosporidium spp. in pre-weaned and post-weaned piglets in Heilongjiang Province, China. PLoS One 8: e67564.

187. Zintl A, Proctor AF, Read C, Dewaal T, Shanaghy N, Fanning S and Mulcahy G (2009). The prevalence of Cryptosporidium species and subtypes in human faecal samples in Ireland. Epidemiology and Infection 137: 270277. 